\title{
Western European Oilfields: An Outline
}

by

A. Perrodon

Oil has been produced in Western Europe since the Middle Ages and, at the industrial level, since the end of the 18th century, though it was only in the 1960 's, with the discovery of the giant gas fields of Holland and the southern North Sea that its potential was fully appreciated. It is clear now, after more than a century of onshore effort, that the North Sea, and in particular the part between British and Norwegian waters, will reap the greatest rewards.

The sedimentary formations of interest in the search for petroleum cover approximately $3.6 \mathrm{M} \mathrm{km}^{2}$, almost $2 \mathrm{M}$ (million) being onshore and $1.6 \mathrm{M}$ offshore in the Atlantic and the Mediterranean. $4.4 \mathrm{Gt}$ (thousand million tonnes) of oil and more than $5,500 \mathrm{Gm}^{3}$ of gas have been found in this area; 3.7 Gt of the oil are situated in the North Sea, though of the total $4.4 \mathrm{Gt}$, only $640 \mathrm{Mt}$ have been produced so far.

Reserves are contained in some 500 fields across 20 petroleum provinces. Amongst them 15 are categorized as "giant" fields (>70 Mt or equivalent in gas), and two-thirds of these are oil-bearing; all of them are situated in the North Sea, with the exception of the three gas (and condensate) fields of Groningen, Lacq and Malossa.

These petroleum provinces are found in formations of Carboniferous to Pliocene age deposited between the Caledonian, Hercynian and Alpine orogenies.

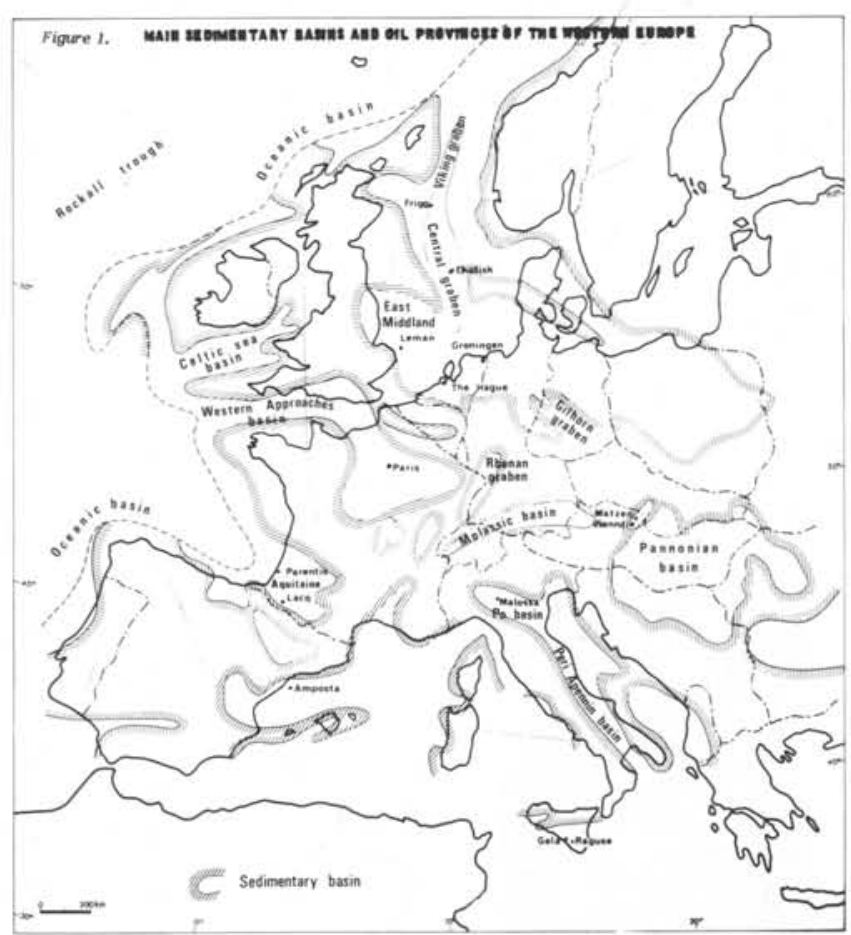

EPISODES, Vol. 1980, No. 1 
Basins of the Carboniferous

In the British Caledonian region, the Carboniferous formations of the East Midland basin (Fig. 1) constitute a very minor province of 12 small fields, the total initial reserves of which do not exceed $3 \mathrm{Mt}$. In northern Germany, the more developed Carboniferous contains 3 (at Rehden in particular) gas deposits of the order of $15 \mathrm{Gm}^{3}$.

\section{Permian basin}

The most important gas reserves are found in the vast Permian basin stretching from southern Great Britain to Poland. The Rothliegende detrital deposits of fluviatile and aeolian origin, supplied by Westphalian Coal Measure beds and effectively capped by Zechstein evaporites, constitute a gas province of major importance. The initial reserves of the basin are estimated at $3,800 \mathrm{Gm}^{3}$, distributed for the most part in the following giant fields: Groningen, $\left(2,650 \mathrm{Gm}^{3}\right)$ in the Netherlands, and Leman $\left(300 \mathrm{Gm}^{3}\right)$, Indefatigable (125 $\left.\mathrm{Gm}^{3}\right)$ and Hewitt $\left(100 \mathrm{Gm}^{3}\right)$ - all in the British zone of the southern Nor th Sea.

The Zechstein can be productive when it has an algal or karstified carbonate facies resulting from ancient submarine highs. Consequently, the Zechstein is a gas reservoir containing almost $200 \mathrm{Gm}^{3}$ among 40 deposits in northern Germany; it is also the principal oil reservoir of the Auk and Argyll fields of the North Sea.

\section{Basins of the Mesozoic}

The Triassic and Jurassic seas covered the greater part of Western Europe, forming vast cratonic basins in which individual troughs of subsidence, with a more or less North-South orientation, were formed, generally displaying excellent petroleum potential.

\section{Mediterranean}

There is a vast mesogean Mesozoic basin in the Mediterranean area, characterized by Triassic source rocks and mainly carbonate reservoirs, whose age depends on that of the caprock. The fields occur in different zones:

- South-West Sicily, with the heavy oil fields of Ragusa and Gela (40 Mt initial reserves);

- Middle Po River Valley with the field of Malossa, producing from Triassic dolomite capped by Cretaceous limestones and Oligocene marls ( $50 \mathrm{Gm}^{3}$ gas and $40 \mathrm{Mt}$ liquid hydrocarbons);

- Periappennine zone, usually producing heavy oil from Cretaceous carbonate reservoirs with a Miocene caprock. Notable fields include David, Rospo Mare, and Maria Mare - a zone which could contain reserves of up to $300 \mathrm{Mt}$;

- Offshore Ebre delta, Spain, also producing from the Cretaceous and in some places from the base of the Miocene. The caprock is formed by transgressive Miocene formations; one-third of total reserves $(30 \mathrm{Mt}$ ) are in the Amposta field.

\section{North Sea/Germany}

In the Nordic area, there are several Jurassic and Cretaceous basins with a N-S orientation. These basins are affected by deformations such as Cimmerian horsts and grabens capped by Kimmeridgian transgressive shales. The different zones of petroleum production share the common characteristic of having originated from Jurassic source rocks.

Important zones include the:

- Gifhorn trough in West Germany, containing initial reserves of $30 \mathrm{Mt}$ among 50 deposits;

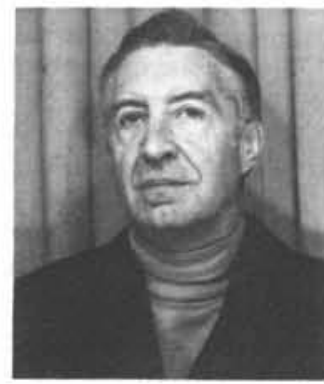

ABOUT THE AUTHOR: President of the French National Committee for Geology and the Geological Society of France, Alain Perrodon heads the geological division of the Elf Aquitaine Group. He also lectures in petroleum geology at the Ecole de Géologie de Nancy, the ENSPM (French Petroleum Institute), and the University of Paris. His past positions include Assistant Exploration Manager in the Bureau de Recherches de Pétrole and Geologist in the Algerian Société Nationale de Recherche et d'Exploitation des Pétroles.
Hague graben, slightly folded, producing oil from the lower Cretaceous (25 Mt);

- Viking and Central grabens of the North Sea, producing from the Liassic and Dogger, capped by Kimmeridgian shales (Statfjord, Brent and Magnus fields), from Eocene-Palaeocene sands (Frigg, Forties) in the northern area, and from Upper Cretaceous chalk (Ekofisk) in the central area.

This province has reserves in the region of $3 \mathrm{Gt}$ oil and 12000 $\mathrm{Gm}^{3}$ gas, mostly in ten giant fields.

\section{Other basins}

Between these two major areas, there extends a series of Mesozoic cratonic basins in which the principal zones of interest are the Jurassic and the Lower Cretaceous.

In northern Germany, the province of Ems is of particular interest, situated astride the Germany-Netherlands border; $40 \mathrm{Mt}$ of petroleum have been discovered in Lower Cretaceous sandstones, half of which lie in the Dutch fields of Schoonebeek.

The Paris Basin, producing oil from Dogger carbonates and contains reserves of $10 \mathrm{Mt}$ among 20 deposits.

Production in the Aquitaine Basin in France is mainly from two zones in the Lower Cretaceous situated on the edge of the platform - the Parentis province in the North (45 Mt oil), and the Lacq zone (about $300 \mathrm{Gm}^{3}$ gas).

\section{Tertiary Basins}

The Alpine orogeny was accompanied by the formation of a number of basins which complement those already in existence. Amongst the most important are the following three Neogene provinces:

- Vienna Basin, Austria where reserves of $100 \mathrm{Mt}$ oil and 100 $\mathrm{Gm}^{3}$ gas have been discovered in 40 deposits, the major part being concentrated in the Matzen field;

- Yugoslav section of the Pannonic Basin with initial reserves of roughly $100 \mathrm{Mt}$ oil and $50 \mathrm{Mm}^{3}$ gas;

- Po plain basins and edge of the Appennine area, particularly rich in gas (roughly $350 \mathrm{Gm}^{3}$ ).

\section{Conclusion}

Western Europe is on the one hand an old petroleum region, with many onshore fields being close to exhaustion; on the other hand however, it is a new region of offshore potential. The most important province, that of the North Sea, was only discovered in the 1960's. New deposits continue to be found onshore especially in deeper horizons, while other offshore basins remain to be explored. Given this and the regional economic conditions, Europe offers strong potential for future exploration.

\section{References}

Kent, P.E., 1975, Review of North Sea Basin development: J. Geol. Soc., 131, p. 435-468.

Perrodon, A., 1963, Esquisse géologique et pétroliere de I'Europe occidentale: Revue Inst. Fr. Pétrole, XVIII/2, p. $171-195$.

Pruvost, P., 1959, La lente construction de l'Europe au cours des temps géologiques: Revue Univ. Mines 9, XV, 8, p. 670682.

Ziegler, P.A., 1978, North Western Europe tectonics and basin development: Geologie en Mijnbouw, Amsterdam, 57, 4, p. 589-626.

Zwart, H.J. and Dornsiepen, U.F., 1978, The tectonic framework of Central and Western Europe: Geologie en Mijnbouw, Amsterdam, 57, 4, p. 627-654. from Lower Cretaceous (Valanginian and Hauterivian) sands, 